\title{
Commentary \\ Natriuretic peptide determinations in critical care medicine: part of routine clinical practice or research test only?
}

Paul O Collinson

Department of Chemical Pathology and Department of Cardiology, St George's Hospital and Medical School, London SW17 0QT, UK

Corresponding author: Paul O Collinson, paul.collinson@stgeorges.nhs.uk

Published: 12 January 2009

Critical Care 2009, 13:105 (doi:10.1186/cc7133)

This article is online at http://ccforum.com/content/13/1/105

(c) 2009 BioMed Central Ltd

See related research by Coquet et al., http://ccforum.com/content/12/6/R137

\begin{abstract}
Measurement of N-terminal pro-B-type natriuretic peptide has been shown a good rule-out test for cardiac dysfunction in patients in the intensive care unit. The peptide measurement should not be used as a replacement for other forms of monitoring, and performs best as a diagnostic test when interpreted together with other clinical findings and investigations. At a cutoff value similar to that found in other clinical studies in acute decompensated heart failure, measurement of $\mathrm{N}$-terminal pro-B-type natriuretic peptide offers an additional tool for diagnostic assessment of patients presenting to the intensive care physician.
\end{abstract}

Measurement of the B-type natriuretic peptide (BNP) and mesurement of the $\mathrm{N}$-terminal portion of the prohormone, $\mathrm{N}$ terminal pro-B-type natriuretic peptide (NTproBNP), are part of the routine assessment of patients presenting with acute dyspnoea. The measurement of BNP/NTproBNP is now included in the recommendations from professional societies.

Coquet and colleagues [1] have studied NTproBNP measurement in the critical care population. They compared the diagnostic performance of NTproBNP using a final diagnosis of cardiac dysfunction based on a combination of clinical and echocardiographic criteria. Using this diagnosis as the dichotomous variable, the authors performed receiver operating characteristic curve analysis and showed that the area under the receiver operating characteristic curve was $0.76(95 \%$ confidence interval, 0.69 to 0.83 ) for the ability of NTproBNP concentrations to detect cardiac dysfunction. In addition, using a composite model including NTproBNP, electrocardiographic changes and severity assessed by the organ system failure score, the area under the receiver operating characteristic curve for a final diagnosis of cardiac dysfunction improved to 0.83 (95\% confidence interval, 0.77 to 0.90 ).

The Breathing Not Properly study, a multicentre evaluation of BNP [2], the N-terminal pro-BNP Investigation of Dyspnoea in the Emergency Department study [3] and the International Collaborative NTproBNP study [4] for NTproBNP clearly demonstrated that measurement of BNP is diagnostically accurate when compared with a consensus final diagnosis of acute heart failure and defined diagnostic cut-off values. The study by Coquet and colleagues found that an NTproBNP value $<500 \mathrm{ng} / \mathrm{l}$ predicted the absence of cardiac dysfunction with a sensitivity of $89 \%$ and a specificity of $43 \%$ [1]. Although age and renal function affect NTproBNP levels, which is reflected in reference ranges for this analyte, diagnostic performance was not significantly affected. This value of $<500 \mathrm{ng} / \mathrm{l}$ is very similar to that proposed by other workers in the field as a rule-out cutoff point for NTproBNP [4].

How should this translate into routine clinical practice? Are NTproBNP measurements good surrogates for invasive haemodynamic monitoring? NTproBNP measurements have been compared with invasive haemodynamic measurements in acute decompensated heart failure and found to show good diagnostic performance [5] and a tight correlation existed between BNP measurement and pulmonary capillary wedge pressure as a dichotomous variable. Other studies have shown in the intensive care unit that correlation between natriuretic peptide measurements and invasively measured haemodynamic parameters in the acute situation are relatively poor [6-8]. When cardiac intensive care patients are used, a more closely defined relationship is seen $[9,10]$. Measurement of BNP or NTproBNP should not be used as a substitute for other monitoring techniques in the intensive care population.

The authors highlight that NTproBNP measurement is most powerful when used as a rule-out test for cardiac dysfunction. They also clearly demonstrate that the diagnostic power is improved when interpreted with other variables. To misquote John Donne, no test is an island. Elevation of NTproBNP

$\mathrm{BNP}=\mathrm{B}$-type natriuretic peptide; NTproBNP = N-terminal pro-B-type natriuretic peptide. 
occurs in a range of other clinical conditions other than cardiac dysfunction, including sepsis [11]. Values are frequently raised in the intensive care population, and both BNP and NTproBNP measurements have been shown to be prognostic in this population [12,13]. BNP and NTproBNP values predict a poor prognosis when markedly elevated the death hormone.

The routine measurement of NTproBNP is certainly extremely valuable as part of the initial assessment of a patient admitted to intensive care as a rule-out test for cardiac dysfunction. This measurement is not a rule-in test, and it is debatable whether NTproBNP measurement should form part of routine monitoring of the patient once they have been admitted.

\section{Competing interests}

The author declares that they have no competing interests.

\section{References}

1. Coquet I, Darmon M, Doise JM, Degres M, Blettery B, Schlemmer B, Gambert P, Quenot JP: Performance of N-terminal-pro-Btype natriuretic peptide in critically ill patients: a prospective observational cohort study. Crit Care 2008, 12:R137.

2. Maisel AS, Krishnaswamy P, Nowak RM, McCord J, Hollander JE, Duc P, Omland T, Storrow AB, Abraham WT, Wu AH, Clopton P, Steg PG, Westheim A, Knudsen CW, Perez A, Kazanegra R, Herrmann HC, McCullough PA: Rapid measurement of B-type natriuretic peptide in the emergency diagnosis of heart failure. N Engl J Med 2002, 347:161-167.

3. Januzzi JL, Jr., Camargo CA, Anwaruddin S, Baggish AL, Chen AA, Krauser DG, Tung R, Cameron R, Nagurney JT, Chae CU, Lloyd-Jones DM, Brown DF, Foran-Melanson S, Sluss PM, LeeLewandrowski E, Lewandrowski KB: The N-terminal Pro-BNP investigation of dyspnea in the emergency department (PRIDE) study. Am J Cardio/ 2005, 95:948-954.

4. Januzzi JL, van Kimmenade R, Lainchbury J, Bayes-Genis A, Ordonez-Llanos J, Santalo-Bel M, Pinto YM, Richards M: NTproBNP testing for diagnosis and short-term prognosis in acute destabilized heart failure: an international pooled analysis of 1256 patients: the International Collaborative of NTproBNP Study. Eur Heart J 2006, 27:330-337.

5. Zhao SQ, Hu YM, Li Q, Liu XR, Wang M, Zhang WY, Wu T, Nie $X L$, Zhao N, Wang LR: The clinical value of rapid assay for plasma B-type natriuretic peptide in differentiating congestive heart failure from pulmonary causes of dyspnoea. Int J Clin Pract 2008, 62:214-220.

6. Forfia PR, Watkins SP, Rame JE, Stewart KJ, Shapiro EP: Relationship between B-type natriuretic peptides and pulmonary capillary wedge pressure in the intensive care unit. J Am Coll Cardiol 2005, 45:1667-1671.

7. Parsonage WA, Galbraith AJ, Koerbin GL, Potter JM: Value of Btype natriuretic peptide for identifying significantly elevated pulmonary artery wedge pressure in patients treated for established chronic heart failure secondary to ischemic or idiopathic dilated cardiomyopathy. Am J Cardio/ 2005, 95:883885.

8. Jefic D, Lee JW, Jefic D, Savoy-Moore RT, Rosman HS: Utility of B-type natriuretic peptide and $\mathrm{N}$-terminal pro $\mathrm{B}$-type natriuretic peptide in evaluation of respiratory failure in critically ill patients. Chest 2005, 128:288-295.

9. Larsen Al, Dickstein K, Ahmadi NS, Aarsland T, Kvaloy JT, Hall C: The effect of altering haemodynamics on the plasma concentrations of natriuretic peptides in heart failure. Eur J Heart Fail 2006, 8:628-633.

10. Knebel F, Schimke I, Pliet K, Schattke S, Martin S, Borges AC, Baumann G: NT-ProBNP in acute heart failure: correlation with invasively measured hemodynamic parameters during recompensation. J Card Fail 2005, 11:S38-S41.

11. Rivers EP, McCord J, Otero R, Jacobsen G, Loomba M: Clinical utility of B-type natriuretic peptide in early severe sepsis and septic shock. J Intensive Care Med 2007, 22:363-373.

12. Rhodes A, Tilley R, Barnes S, Boa F, Grounds R, Collinson P, Bennet E: A prospective study into the use of NT-proBNP measurements in critically ill patients. Clin Intensive Care 2004, 15:31-36.

13. Almog $Y$, Novack V, Megralishvili R, Kobal S, Barski L, King D, Zahger D: Plasma level of $\mathrm{N}$ terminal pro-brain natriuretic peptide as a prognostic marker in critically ill patients. Anesth Analg 2006, 102:1809-1815. 